\title{
Proceeding
}

\section{Pilot study on the testing of Power Glove applied to volleyball}

\author{
FEDERICA FERRARA 14 , RICCARDO IZZO², ANDREA CECILIANI ${ }^{3}$, ALFREDO PIO DI TORE ${ }^{4}$ \\ 1 University of Salerno, Italy \\ 2University of Carlo Bo of Urbino, Italy \\ 3 University of Bologna, Italy \\ 4 University of Foggia, Italy
}

\begin{abstract}
As introduced in the preliminary study previously carried out, the spread of technology in sports provides a monitoring of objective activity, accurate and not invasive. This led to the creation of a technological instrument, Power Glove, which investigates specific aspects of sport performance. The aim of this study is to evaluate the difference of serve performances through a test, to establish its feasibility and to obtain information that will allow to determine the calibration of the final instrument, taking into account the metrological characteristics of a measuring instrument. The carried out test, considers the serve, one of the fundamentals of volleyball, which starts ay every action of the game. The study was conducted on a sample divided into two groups: group A composed of 12 female volleyball players aged 12-16 years; and group B composed of 10 female volleyball players aged 18-25 years. It is a controlled and designed clinical study method in which subjects are exposed to various tests of strength, speed and precision in an alternated or simultaneous and supervised manner. Key words: Serve; Training method; Anthropometric; Performance; Skill test.
\end{abstract}

\section{Cite this article as:}

Ferrara, F., Izzo, R., Ceciliani, A., \& Di Tore, A.P. (2019). Pilot study on the testing of Power Glove applied to volleyball. Journal of Human Sport and Exercise, 14(2proc), S233-S238. doi:https://doi.org/10.14198/jhse.2019.14.Proc2.11

Corresponding author. University of Salerno, Italy.

E-mail: aciredef2212@gmail.com

Supplementary Issue: Winter Conferences of Sports Science. Costa Blanca Sports Science Events, 25-26 January 2019. Alicante, Spain.

JOURNAL OF HUMAN SPORT \& EXERCISE ISSN 1988-5202

(C) Faculty of Education. University of Alicante.

doi:10.14198/jhse.2019.14.Proc2.11 


\section{INTRODUCTION}

In the technical characteristics of volleyball, accuracy is one of the most important aspects. Serve is one of the fundamental elements of volleyball, and it starts every game action (Parisi, F., Raiola, G. 2014). By fundamental we mean a specific action that the volleyball player does (D'lsanto. et al. 2017). They are defined as fundamental because they must be part of the technical baggage of each athlete. The service can be trained in game conditions and theoretically has the highest degree of efficiency. When an athlete acquires a new movement, it can be noted that the execution of this gesture turns out to be inaccurate or wrong (Raiola, G., et al 2016). Through the repetition of the same skill, the motor model is strengthened and created (Raiola, G. 2017). Repetition can also be useful in improving an already acquired ability. The purpose of this study is to investigate the difference in server performance by analysing the possible difference in performance that can be obtained during the execution of the service with the aid of a technological tool, or the Power Glove, on the athletes (Ferrara, Di Tore, 2018). This type of detection avoids all the interferences connected to the laboratory settings: "An athlete studied in laboratory conditions could perform very differently in the field» (Armstrong, 2007), allowing to investigate the performance without altering the "natural" scenario (Parisi, F., Raiola, G. 2014). The device consists of a glove, which can be worn by the athlete, equipped with various ultra-thin sensors (such as not to affect performance). The sensors are operated by an Arduino Nano micro controller, worn at arm level by a bracelet. The basic sensor is a flexible and ultra-thin TekScan pressure sensor $(<0.1 \mathrm{~mm})$, able to detect the pressure exerted by the hand on the ball in a range between 0 and $100 \mathrm{~kg}$ with a precision of $100 \mathrm{~g}$ and a sampling frequency of $100 \mathrm{~Hz}$ (Di Tore P.A., Raiola G., 2019).

The feedback method is increasingly used to acquire new skills and improve performance. Various studies have reported that objective and quantitative feedback leads to improved performance (Raiola, G., et al 2013).

\section{Aim}

The purpose of performance analysis is to improve knowledge of parameters that affect performance (D'santo et al., 2019). In team sports, this information allows us to become familiar with the dynamic system involved in these sports (Raiola, G. 2014). In addition, it provides reference values and criteria to the coaches who can be used to guide the training process and prepare the teams for the needs of their sport and their opponents, but above all, improve the technical gestures of the individual athletes (D'Elia, et al., 2018).

\section{METHODS}

Study method is clinical, controlled and designed, in which the participants are assigned to the different modalities of intervention in the same period of time, and in a supervised manner. Through the pilot study the suitability of the project is verified, therefore the necessary information is obtained to then determine the characteristics of the definitive study. The study will be conducted on a sample divided into 2 groups: group A composed of 12 female volleyball players aged 12 to 16 , and group B composed of 10 players aged 18 to 25 years. The study makes use of physical and anthropometric tests. The tests were selected on the basis of disemplicity, objectivity and reproducibility parameters (Forte, D., Altavilla, G. 2018). For each of them the criteria to be measured and executed have been indicated.

\section{Anthropometric tests}

1. Height: it must be calculated placing the athlete (barefoot) with the shoulders to a wall, the heels adhering to the wall and using a team (recommended unit $0.5 \mathrm{~cm}$ ); 
2. Weight: the barefoot athlete climbs on a scale, possibly digital;

3. Reach with one hand: the athlete with the right flank adhering to the wall (left for left-handed people) and with adherent and parallel feet extends the arm as high as possible on the marked wall;

4. Reach with two hands: the athlete standing perpendicular to the wall, face facing the wall, spreads his arms as high as possible on the marked wall, the measure must be calculated on the maximum height reached by the lower hand.

The following values are calculated:

- BMl, body mass index, is the result of weight $(\mathrm{kg})$ divided by the square of height (in square $\mathrm{m}$ ). If the BMI is <18.5, a subject is underweight; if it is between 18.5 and 24.9 it is normal weight; if and between 25 and 29.9 it is overweight; if finally it is $>30$ it is obese.

- The ratio between one-hand reach and height; this index, also conditioned by other factors, indicates the degree of longitude of the observed subject. Indicatively it varies between 20 and 36 and in volleyball it is very important.

BMI provides an estimate of body fat. In a performance of an athletic gesture in suspension attitude, the BMI goes to influence the differential from the ground. To jump high, a volleyball player must exert a force against the ground, this force is applied while the feet are in contact with the ground and while the body is raised against gravity. Therefore the weight of the subject affects the elevation and strength (D'isanto, T., et al 2018).

\section{Test of strength}

Launching a ball into a sitting position.

The test aims to measure the explosive strength of the upper limbs, which is influenced by the degree of coordination of the athlete and the length of the limbs.

Material: $1 \mathrm{~kg}$ medicine ball; chair without arms of adequate height; double decametre.

Description: The decametre is placed on the ground with the zero corresponding to the ground projection of the inside of the chair. The athlete, seated with the trunk resting on the backrest, takes the $1 \mathrm{~kg}$ medicine ball with two hands and lances it from the chest forward as far as possible without taking the shoulders off the back. Measurement: From the projection of the inside of the back to the point of arrival. Three tests are carried out in succession and the best one is recorded;

\section{Speed Test}

The test evaluates the rapidity of movement of the upper limbs. Material: $1 \mathrm{~m}$ long wood rod.

Description: from the standing station, with the feet slightly apart, the athlete holds a wooden rod about $1 \mathrm{~m}$ long and the $\mathrm{dm}$ of $2-3 \mathrm{~cm}$, with a step equal to the width of the shoulders. The athlete pushes forward as quickly as possible, extending his arms to the maximum and always returning with the wand on his chest. Measurement: count the number of thrusts performed in 8 seconds. Perform 3 tests interspersed 3 minutes, choosing the best one.

Accuracy Test

The test evaluates the accuracy of the launch.

Material: tennis ball, mattress. 
Description: From the end of the field, throw a tennis ball down from the top with a descending trajectory, trying to hit the mat in the opponent's field at a height of 4 meters. Measurement: count the number of positive throws made in 3 tests composed of 5 shots each interspersed by 3 minutes.

Test to evaluate the effectiveness of the service based on the repetition of the technical gesture to improve performance. Model of training technique that is mainly applied for the improvement of individual actions, as the same actions are "apparently" repeated. The test consists of 2 sets of 8 bars each in the direction of a target placed in the opposing field (eg p1 vs p5 or p1 vs p1).

In volleyball the development of cognitive skills plays an important role (Di Tore A.P. et al., 2018). Learning and analysing and resolving situations, associated with high decision-making capacity under time pressure (Tore, A.D., et al 2018).

The device allows to overcome the known technique and to obtain an accurate and non-invasive monitoring of physical activity. The transmission of data from the sensor in real time means that the training methods can be modified and evolved based on the analysis of the athlete's performance.

The technological tool in fact facilitates the analysis of the technical gesture of the measure for the improvement and precision of the specific technical gesture, but also allows more effective teaching methods.

Powerglove collects information on strength, surface, impact time and direction in service. The collected data, correlated to the results of the tests above, allow an exhaustive analysis on the precision of the technical gesture (Ferrara, Di Tore, 2018).

\section{Expected results}

This study will include physical and anthropometric tests on the speed and precision of the athletes, and a further qualitative and quantitative test to evaluate the effectiveness of the service. The results will be useful for identifying errors and for analysing the causes that lead to them.

\section{CONCLUSIONS}

The expected result is an improvement of the technical gesture and the accuracy of the service in the athletes. From this study it will be possible to obtain useful data and interpretations for a more detailed experimental study.

\section{REFERENCES}

Altavilla, G., Di Tore, P.A., Riela, L., D'Isanto, T. (2017) Anthropometric, physiological and performance aspects that differentiate male athletes from females and practical consequences, Journal of Physical Education and Sport, 17, 2183-2187.

Altavilla, G., Gaetano, R. (2018) Physiological effects of warm-up and problems related to team sports, Sport Science, 11, 83-88.

Altavilla, G., Mazzeo, F., D'Elia, F., Raiola, G. (2018) Physical commitment and specific work for each role in an elite soccer team, Journal of Physical Education and Sport, 18 (2), 570-574.

D'elia, F., Mazzeo, F., Raiola, G. (2018) The core curriculum in the university training of the teacher of physical education in Italy, Journal of Human Sport and Exercise, 13(Proc2): S413-S420. https://doi.org.10.14198/ihse.2018.13.Proc2.25 
D'Isanto, T., Altavilla, G., Raiola, G. (2017) Teaching method in volleyball service: Intensive and extensive tools in cognitive and ecological approach. Journal of Physical Education and Sport, 17, 2222-2227.

D'Isanto, T., D'Elia, F., Raiola, G., \& Altavilla, G. (2019). Assessment of sport performance: theoretical aspects and practical indications. Sport Mont, 17(1), 79-82. https://doi.org/10.26773/smj.190214

D'Isanto, T., Di Tore, P. \& Altavilla, G. (2018). Correlation of the anthropometric characteristics and the ability to jump in volleyball. Journal of Human Sport and Exercise, 13(2proc), S393-S400. https://doi.org/10.14198/ihse.2018.13.Proc2.23

Di Tore, P.A., Raiola, G., Altavilla, G., Barba, S., Pignato, S., Lipoma, M. (2016) Motor imagery, perspective taking and gender differences: A VVIQ2-based study. Journal of Human Sport and Exercise, 11 228-232. https://doi.org/10.14198/jhse.2016.11.Proc1.13

Di Tore, P.A., Raiola, G., Altavilla, G., Gervilli, M.G., Pignato, S., Lipoma, M. (2016) Visual motor skills and reading fluency: A correlational study. Journal of Human Sport and Exercise, 11(Proc1): S233S238. https://doi.org/10.14198/ihse.2016.11.Proc1.14

Di Tore, A.P., Raiola, G., D'Isanto, T. (2018) Situation awareness in sports science: Beyond the cognitive paradigm [Situacijska svijest u sportskoj nauci: Van kognitivne paradigme], Sport Science, 11 (1), 44-48.

Di Tore P.A., Raiola G.(2019) Powerglove: Genesis of a wearable technology aimed at studying volleyball service, Journal of Physical Education and Sport.

Di Tore, P.A., Raiola, G. (2012) Exergames in motor skill learning, Journal of Physical Education and Sport, 12 (3), 358-361.

Ferrara. F., Di Tore. P.A, (2018) Preliminary work on the testing of Power Glove applied to volleyball, Journal of Physical Education and Sport, 18.

Forte, D., Altavilla, G. (2018) Preliminary correlation between anthropometric and performance data in volleyball about the transition period Journal of Physical Education and Sport, 18, 1994-1998.

Gaetano, R. (2012) Didactics of volleyball into the educate program for coaches/trainers/technicians of Italian Federation of Volleyball (FIPAV). Journal of Physical Education and Sport, 12 (1), pp. 25-29.

Parisi, F., Raiola, G. (2014) The serve in under 12-13 Italian volleyball team. Journal of Human Sport and Exercise, 9, 588-591. https://doi.org/10.14198/ihse.2014.9.Proc1.51

Parisi, F., Raiola, G. (2014) Video analysis in youth volleyball team, Journal of Human Sport and Exercise, 9, 584-S587. https://doi.org/10.14198/jhse.2014.9.Proc1.50

Polidoro, L., Bianchi, F., Di Tore, P.A., Raiola, G. (2013) Futsal training by video analysis, Journal of Human Sport and Exercise, 8 (2), pp. 290-296. https://doi.org/10.4100/jhse.2012.8.Proc2.31

Raiola, G. (2012) Bodily communication in volleyball between human and experimental sciences, Mediterranean Journal of Social Sciences, 3 (1), 587-597.

Raiola, G. (2014) Teaching method in young female team of volleyball, Journal of Physical Education and Sport, 14 (1), 74-78.

Raiola, G. (2017) Motor learning and teaching method, Journal of Physical Education and Sport, 17, 2239-2243.

Raiola, G., Altavilla, G., De Luca, C., Di Tore, P.A. (2016) Analysis on some aspects of the service in volleyball, Sport Science, 9 (1), 74-77.

Raiola, G., D'Elia, F., \& Altavilla, G. (2018). Physical activity and sports sciences between European research council and academic disciplines in Italy. Journal of Human Sport and Exercise, 13(2proc), S283-S295. https://doi.org/10.14198/jhse.2018.13.Proc2.13

Raiola, G., Di Tore, P.A. (2017)Motor learning in sports science: Different theoretical frameworks for different teaching methods [Motoričko učenje u sportskoj znanosti: Različiti teorijski okviri za različite metode poučavanja] Sport Science, 10, 50-56. 
Raiola, G., Parisi, F., Giugno, Y., Di Tore, P.A. (2013)Video analysis applied to volleyball didactics to improve sport skills, Journal of Human Sport and Exercise, 8 307-313. https://doi.org/10.4100/ihse.2012.8.Proc2.33

Tore, A.D., Altavilla, G., D'Isanto, T. (2018) Situation awareness in sports science: Beyond the cognitive paradigm, Sport Science, 11 (1), 25-28.

\section{(c) $(\mathrm{T})($}

This work is licensed under a Attribution-NonCommercial-NoDerivatives 4.0 International (CC BY-NC-ND 4.0). 